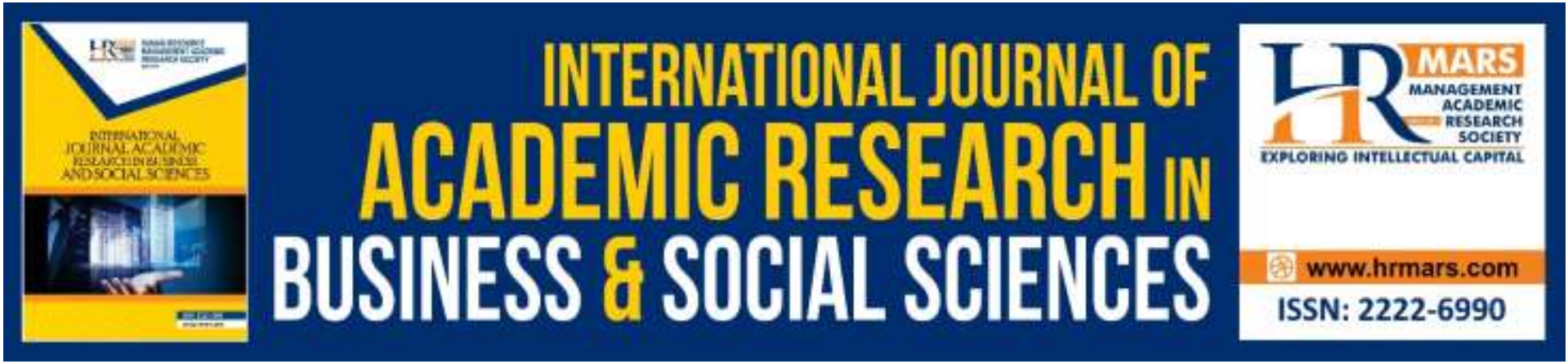

\title{
The Effects of Motivation, Empowerment and Organizational Culture on Organizational Commitment of Municipalities in Jordan
}

Othman Hussein Al-Bataineh, Rashldah Binti Mohammad Ibrahim, Ahmad Firdause Md Fadzil

To Link this Article: http://dx.doi.org/10.6007/IJARBSS/v9-i9/6272

DOI: 10.6007/IJARBSS/v9-i9/6272

Received: 12 June 2019, Revised: 11 July 2019, Accepted: 24 August 2019

Published Online: 08 September 2019

In-Text Citation: (Al-Bataineh, Ibrahim, \& Fadzil, 2019)

To Cite this Article: Al-Bataineh, O. H., Ibrahim, R. B. M., \& Fadzil, A. F. M. (2019). The Effects of Motivation, Empowerment and Organizational culture on Organizational Commitment of Municipalities in Jordan. International Journal of Academic Research in Business and Social Sciences, 9(9), 101-117.

\section{Copyright: (C) 2019 The Author(s)}

Published by Human Resource Management Academic Research Society (www.hrmars.com)

This article is published under the Creative Commons Attribution (CC BY 4.0) license. Anyone may reproduce, distribute, translate and create derivative works of this article (for both commercial and non-commercial purposes), subject to full attribution to the original publication and authors. The full terms of this license may be seen at: http://creativecommons.org/licences/by/4.0/legalcode

\section{Vol. 9, No. 9, 2019, Pg. 101 - 117}

Full Terms \& Conditions of access and use can be found at http://hrmars.com/index.php/pages/detail/publication-ethics 


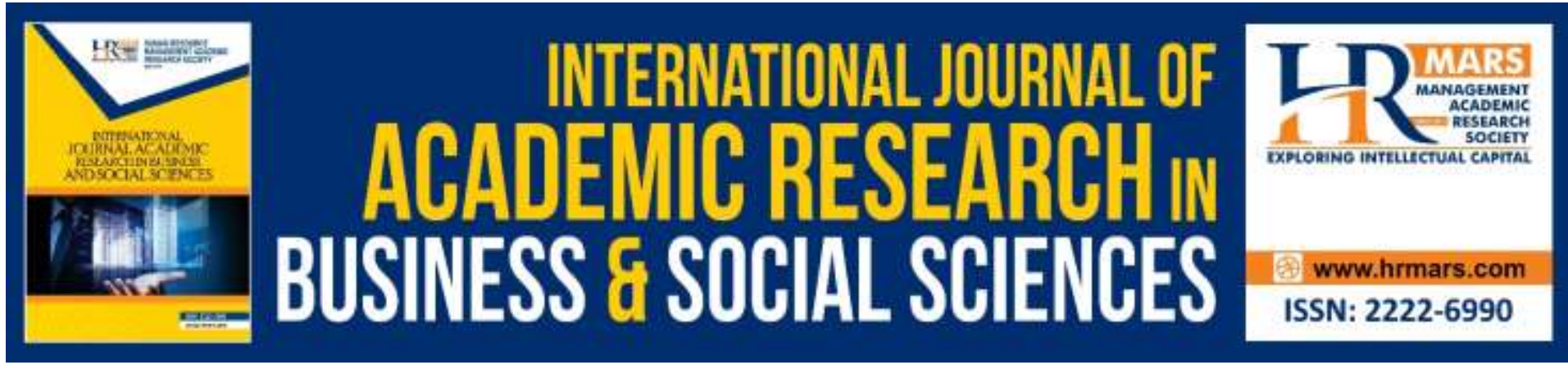

\title{
The Effects of Motivation, Empowerment and Organizational culture on Organizational Commitment of Municipalities in Jordan
}

\author{
Othman Hussein Al-Bataineh \\ Alqudwa cultural center, Irbid, Jordan \\ Email: batainehothman@yahoo.com
}

\author{
Dr. Rashldah Binti Mohammad Ibrahim \\ Faculty of Business and Management Universiti Sultan Zainal Abidin \\ Terengganu, Malaysia \\ Email: rashidahmi@unisza.edu.my \\ Dr. Ahmad Firdause Md Fadzil \\ Faculty of Business and Management, Universiti Sultan Zainal Abidin \\ Terengganu, Malaysia \\ Email: Firdause@unisza.edu.my
}

\begin{abstract}
Serving quality services to the customers and various stakeholders is the main motto of municipalities in Jordan with regard to support socio economic development within its particular jurisdiction. However, in the Jordanian context, the municipalities are identified to have massive debts and this indicates that self-generated revenue is not sufficient for municipalities to accept their mandated roles as engine of growth for the community. Moreover, several municipalities are allied with poor governance, wastage as well as corruption and maladministration as evidenced from upsurge in the size of indebtedness. Thus, this study investigates the effects of Motivation, Empowerment and Organizational Culture (OC) on organizational commitment (DCO) of municipalities in Jordan. Very few empirical research has been conducted on this ground using these variables in a single model in Jordan. Hence, a structured survey was conducted and selected 340 government officials via cluster random sampling. The hypotheses were tested using SEM-PLS3 based on social exchange theory. Based on the statistical results, there is a significant effect of Motivation, Empowerment and Organizational Culture (OC) on organizational commitment (DCO). Subsequently, the findings evoked that there is a dire need to focus on Motivation, Empowerment and Organizational Culture to get better commitment from the municipalities in Jordan.
\end{abstract}


Keyword: Organizational Commitment, Motivation, Empowerment, Organizational Culture, Municipalities

\section{Introduction}

According to Grönroos (2016) around the world service industry has generate more than 50 percent of GDP and total employment in the developed countries. Whereas, the service industry in this part of the world particular in Jordan has also grown substantially corresponding to the increasing development in the world. However, services provided by the municipalities to the local community are not in a good shape though service industry is growing in Jordan. Basically, local government is under the dominion of the central government in Jordan and the power of decision making is kept in the hand of the local government to manage within its locality (Henson and Beehr 2018).

Moreover, the massive urbanization of local zones which connect considerably with the nation's economic progress causes of complications concerning city governance and thus, municipalities are feeling incredible pressure to provide quality services to the locality in Jordan (Zohar and Polachek 2017). Furthermore, several municipalities are allied with poor governance, wastage as well as corruption and maladministration as evidenced from upsurge in the size of indebtedness (Agyapong 2017). Hence, improving the municipality and converting its precious human capital to deliver excellent and better quality services to the stakeholders and its clients in the 21st century in Jordan is obligatory (Rose-Ackerman 2017). Consequently, in this stage it is necessary to investigate how to upgrade municipal service quality, and to decide what interventions are required, and to recognize the fundamental issues in overcoming the current problems faced by municipalities in Jordan (Bowen, CradockHenry et al. 2017). Hence, this study examines Motivation, Empowerment and Organizational Culture which can effect on organizational commitment of municipalities offices in Jordan.

\section{Problem Statement}

The huge size of debt, high ratio salary to budget, a lot of complements for delay services, the relationship between employees, weak management and corruption, it is therefore essential to understand how to improve municipal service delivery, table 1 shows that ratio of salary to the size of the budget and huge debts on Jordanian municipalities and it has been noted that the major problem facing many municipalities is the small revenue generated especially from the poorer areas such as Mafraq and AJjlun (ministry of municipal affairs, 2016). This factors motivate the researcher to do this study to determine what interventions are necessary, and to understand the underlying issues in overcoming the current problems faced by Jordanian municipalities sector. 
Table 1: Ratio of salaries to the size of the budget

\begin{tabular}{|c|c|c|c|c|c|c|}
\hline NO & Municipality & revenue & salaries & $\begin{array}{l}\text { Budget } \\
\text { size }\end{array}$ & $\begin{array}{l}\text { Budget } \\
\text { deficit }\end{array}$ & $\begin{array}{c}\text { Salaries } \\
\text { Ratio/ } \\
\text { budget size }\end{array}$ \\
\hline 1 & $\begin{array}{l}\text { Irbid Greater } \\
\text { Municipality }\end{array}$ & 5039336 & $18,152,103$ & $41,417,253$ & $6,000,000$ & $44 \%$ \\
\hline 2 & $\begin{array}{l}\text { Madaba Greater } \\
\text { Municipality }\end{array}$ & 1907977 & $3,874,800$ & $8,112,848$ & ---------- & $48 \%$ \\
\hline 3 & $\begin{array}{l}\text { Taffela Greater } \\
\text { Municipality }\end{array}$ & 1562568 & $2,724,300$ & $5,997,138$ & $1,796,000$ & $45 \%$ \\
\hline 4 & $\begin{array}{l}\text { Salt Greater } \\
\text { Municipality }\end{array}$ & 1843232 & $3,793,250$ & $11,235,924$ & ---------- & $34 \%$ \\
\hline 5 & $\begin{array}{l}\text { Mafraq Greater } \\
\text { Municipality }\end{array}$ & 1815461 & $3,186,572$ & $7,523,439$ & ---------- & $42 \%$ \\
\hline 6 & $\begin{array}{l}\text { Jarash Greater } \\
\text { Municipality }\end{array}$ & 1675327 & $3,822,300$ & $10,726,124$ & $5,190,922$ & $36 \%$ \\
\hline 7 & $\begin{array}{l}\text { Maan Greater } \\
\text { Municipality }\end{array}$ & 916125 & $1,929,914$ & $4,973,890$ & $1,269,255$ & $39 \%$ \\
\hline 8 & $\begin{array}{l}\text { Ajlun Greater } \\
\text { Municipality }\end{array}$ & 1295753 & $1,973,788$ & $5,047,757$ & 296,841 & $39 \%$ \\
\hline 9 & $\begin{array}{l}\text { Zarqa Greater } \\
\text { Municipality }\end{array}$ & 3457309 & $19,048,300$ & $41,343,633$ & $7,085,083$ & $46 \%$ \\
\hline 10 & Rusaiffa Greater & 2918477 & $5,911,000$ & $14,070,400$ & ---------- & $42 \%$ \\
\hline 11 & $\begin{array}{l}\text { Karak Greater } \\
\text { Municipality }\end{array}$ & 2257114 & $4,338,894$ & $11,069,588$ & 500,066 & $39 \%$ \\
\hline
\end{tabular}

\section{Background of Jordanian Municipalities}

The Jordanian Municipalities is a historical component of the local government in Jordan. Since the establishment six municipalities since the late 19th century CE. The first municipality was established, it was the municipality of Irbid, which was established in 1881, followed by the Municipality of El-Salt in 1887, Karak in 1893, Ma'an Municipality in 1898, Amman Municipality 1909, and Jerash Municipality 1910, to reach the number of Municipal councils at the beginning of 2001 to 99 municipal councils. (Annual report, ministry of municipalities, 2014).

In this study will be highlighted on first category municipalities. because of the large numbers of staff in them and also because it covers a greater area of service delivery compared to the municipalities of the second and third category, as well as the many challenges facing the first category municipalities such as the huge size of debts, high ratio salaries compared With the budget, the absence of work and financial and administrative corruption.

According to World Bank (2017), the Ministry of Municipal Affairs is pursuing its new strategic plan for the years (2015-2020) approved by the Council of Ministers focused on three reformist approaches: Legislative reform, reform of financial, Administrative reform. Each of the three axes included a set of measures. In the legislative aspect, the ministry prepared a project the new Municipal Law No. (41) for the year 2015, which has been adopted in all its constitutional stages and is being amended, a wide range of laws and regulations are in line 
with new requirements and international standards following the amendment of the Municipalities Law, as for financial reform, the Ministry and the Council of Ministers have multiplied the share of financial municipalities of the revenues of hydrocarbons from (100) million to reach (220) million USD annually, and municipalities were also provided with provisions (75) million for the implementation of asphalt mixes for municipal streets in cooperation with the Ministry of Public Works and Housing.

\section{Literature Review \\ Organizational Commitment (DOC)}

Gao-Urhahn, Biemann et al. (2016) claimed that organization's commitment is the emotional bonding of a person has with an organization which helps to ensure high organization productivity. Whereas, (Smith, Whitman et al. 2017), mentioned that DOC is a sense of identification, participation, and loyalty expressed by a member towards the corporation when an individual brings into line very closely with the program, objectives, and system of the institute. Moreover, DOC is classically linked to the characteristics, the occupations and performances of staff and the sociocultural, environmental of an organizational (Porter, Riesenmy et al. 2016). Mendes and Jesus (2018), Pointed out that commitment is the connection between individual and individual behaviour, which the individuals have to depend each other and have responsibility for their actions and behaviour with the organization. The definitions associated with organizational commitment, commonly relate the behaviour to the attitude of the employee (Mueller and Lee 2002). Mathieu and Zajac (1990) confirms that DOC as being the personal attachment between the employees, and the goals of the organizations, further describe the traits of committed employees as the ones willing to stay with the institution in times of need, and express their commitment by attending work regularly, working a full day and willing to do extra, looks after company assets, and feels being a part of the vision and mission of the institution. Hence, organizational commitment indicates the employee and organization relationship on which employee belongs to organization and organization also belongs to employee for better and superior performance.

\section{Motivation and Organizational Commitment}

Motivation is concerned with the factors that influence people to behave in certain ways (Armstrong 2016). It includes factors that cause, channel, and sustain human behaviour in a particular committed direction. For the purpose of this study it is defined as a means by which organization solicit the efforts of its employees for the job done so as to attain the organizational goals. Motivation can either be intrinsic and extrinsic, depending on the type of employees, nature of the job and the working environment. In other means words, motivation is a means to reduce the gap which exists between the individual's actual state and some desired state.

Motivation and commitment are closely related concepts (Van der Voet, Steijn et al. 2017). The higher the employees motivation the more they are committed with their jobs (Laschinger, Read et al. 2016). Motivation and commitment theory that both developed in an attempt to understand, predict, and influence employee behaviour. As we noted at the outset, however, motivation theorists have generally been more concerned with explaining task performance. This is clearly reflected in Locke (1997) model. In contrast, commitment theorists have historically focused more on explaining employee retention or turnover. The 
latter has clearly changed, however, as is evident in Meyer and Herscovitch (2001) model where predictions are made concerning the effects of commitment on any behaviour (focal or discretionary) of relevance to the target of that commitment. Therefore, in light of the obvious overlap in purpose and implication, we argue that integration of commitment and motivation theory is both plausible and warranted (Meyer and Allen 1997). In this study will be discussed the motivation by sub dimensions: appreciation, facilities, promotion \& growth, reward.

Considering the problem above, motivation and commitment reveals an obvious similarity: Both have been described as energizing forces with implications for behavior. however, that Pinder (1998) describes motivation as a set of energizing forces and that (Yokel, Allen et al. 1994, Meyer and Herscovitch 2001) defined commitment as a force that binds an individual to a course of action. This implies that motivation is a broader concept than commitment and that commitment is one among a set of energizing forces that contributes to motivated (intentional) behaviour.

$\mathbf{H}_{1}$ : motivation effect positively of organizational commitment.

\section{Empowerment and Organizational Commitment}

According to (Thomas and Velthouse 1990) empowerment admirers are expected to have more freedom to take decisions and feel extra responsibility is given, which in line increases the level of commitment of them to their organizations. Han, Seo et al. (2016) identify both straight and circuitous influences of deformation leadership on organizational commitment via emotional empowerment and they mentioned there is straight significant influences of deformation leadership on organizational commitment. Khanjari (2017) also found direct effect of empowerment on commitment. Kabat-Farr, Cortina et al. (2018) claim that emotional empowerment as predictor of organizational commitment. However, emotionally empowered persons have a habit to consider that they are creating a difference in expressive ways, which results in performance for the sake of their organization and at top levels of organizational commitment (Khansa, Barkhi et al. 2018). Furthermore, the degree to which empowerment touches supervisors and general staff will differ among organizations to organizations. It will be contingent partially on the willingness of top administrators to let go control and form work partnerships with their juniors, and partially on the training the staff has received to grow the skills required for agreeable new responsibilities. According to Conger and Kanungo (1988), empowerment of employee encourages employees to work by assigning right from a top level to the low level in an organization. Liden, Wayne et al. (2000) claimed that employees are inspired in their work when they are empowered and the empowering ability can support to create a solid feeling for supported employee that sequentially signifies they are eager to address for the organization. Thus, empowerment is directly allied with organizational commitment. Based on the findings of past studies, this research proposes the following hypothesis:

$\mathbf{H}_{\mathbf{2}}$ : Empowerment effect positively on organizational commitment.

\section{Organizational Culture and Organizational Commitment}

There are also many organizational researchers who have examined corporate culture and commitment as sources of competitive advantage and have used many models to assess these two concepts and the interrelationships between organizational culture and organizational commitment (Mustafa, Ilyas et al. 2016). Hartnell, inicki, Lambert, Hartnell, 
Kinicki et al. (2016) described organizational culture and commitment to predict organizational commitment from organizational culture. The results revealed that organizational commitment at compliance level is predicted from power and role cultures, while organizational commitment at identification and internalisation levels is predicted from achievement and supports cultures. Masouleh and Allahyari (2017) investigated administrative faculty and staff perceptions of organizational climate and commitment in Christian higher education. Masouleh and Allahyari (2017) conducted a survey to examine differential effects of organizational culture and organizational commitment on the organization. The hierarchical regression results indicate that perception of creative organizational culture, affective and continuance commitment leads to foster positive relationship with the organization. The study also reveals that creative organizational culture is more positively related to the learning organization than affective and continuance commitment. . In this study, it is hypothesized that employee perceptions of their organizational climate would be statistically effect to their degree of organizational commitment.

Furthermore there is various empirical research evidence that establishes meaningful association between culture of organization and employee attitude at work place leading to noticeable behavioural outcomes. The cultural characteristics of an organization including beliefs, corporate values and norms have been reported to be related with commitment (Mustafa, llyas et al. 2016)). Jones (2017) and Mustafa, llyas et al. (2016) postulate that lower employee commitment can be a result of a rigid organizational culture while positive organizational commitment is an obvious outcome of collaborative work environments. The eminent researchers define culture of an organization by different aspects; organizational culture is set of beliefs, norms and values, being exhibited by the employees' in an organization (Mustafa, llyas et al. 2016).

$\mathbf{H}_{3}$ : organizational culture effect positively on organizational commitment.

\section{Research Gap}

In the Jordanian context, studies of commitment in the municipal sector are still scarce and although commitment has evident implications on the employees of the organization and on the organization itself. This leaves a gap in literature concerning the implications of commitment in municipal sector in Jordan. Therefore, in the current study, commitment is examined in the Jordanian municipal sector to contribute to minimizing the gap in literature and to resolve organizational issues in this context. Moreover currant study compare some important factors together as motivation, empowerment, organizational culture and organizational commitment to reduce the theoretical gap since the previous researches focusing on single factor. This study compare all this Factors in one model to present depth understanding to the commitment in municipalities sector to reduce the gap in literature.

\section{Conceptual Framework}

The research framework as depicted in figure 1 has three independent variables or exogenous constructs that are Motivation, Empowerment and Organizational Culture. All of them are higher order constructs having four dimensions (i.e., Appreciation, Facilities, Promotion\& Growth, Reward) in Motivation construct, (meaning, competence, self-determination, and impact) in Empowerment construct and (Adaptability, Mission, Involvement, Consistency) in OC construct. On the right side of the model Organizational Commitment is placed as a 
dependent variables or used as endogenous construct, while is also having three dimensions (i.e. affective, continuance, and normative) in the model. This research work used the social exchange theory as an underpinning theory since the social exchange theory postulates that relationships begin and are developed by one party doing a favour for the other, with the other party reciprocating. There is an underlying assumption that empowerment and motivation are based on initial effort exerted by an individual, which is then reciprocated through a series of further exchanges (Liao, Wayne et al. 2017).

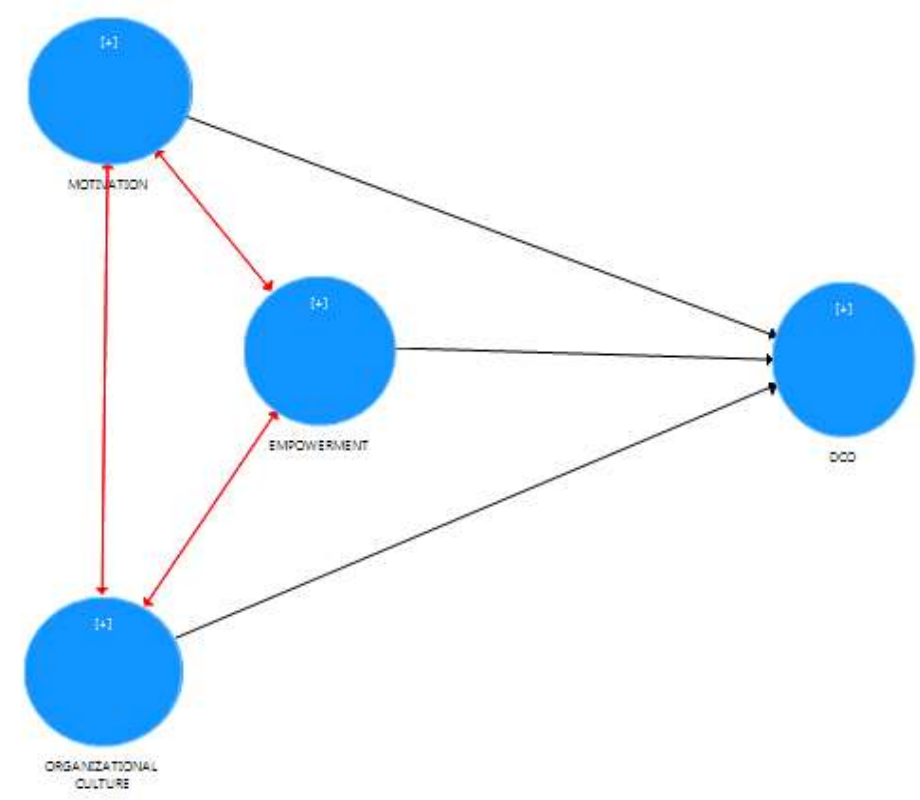

Figure 1. Research Framework

\section{Research Methodology}

The Jordanian first category municipalities were targeted. In this regard, a structured survey was conducted and selected 340 employees via cluster random sampling. The hypotheses were tested using Partial Least Squares (PLS). Since, PLS is a second generation method of multivariate analysis technique hence, SEM- PLS3 is used in this study (Awang, 2015).

\section{Instrumentation}

For Motivation construct, this study adapted and customized items from the research done by Khan and Iqbal (2013). Consequently, this study utilized a total of eighteen (18) items to measure Motivation as a construct and the items were grouped into four dimensions namely, Appreciation, Facilities, Promotion\& Growth and Reward. For Empowerment construct, this study adapted and customized items from the research done by Spreitzer (1995) Consequently, this study utilized a total of fifteen (15) items to measure Empowerment as a construct and the items were grouped into four dimensions namely, meaning, competence, self-determination, and impact For Organizational Culture (OC) construct this study adapted and customized ten (20) items which were grouped into four components for measuring from the research done by Lê and Bùi (2017). Whereas, from the work of Meyer, Allen et al. (1993), this study adapted and customized eighteen (18) items which were grouped into three dimensions, namely affective, continuance, and normative for measuring organizational commitment construct. This study used 5-point interval scale with 1 representing to strongly disagree and 5 as strongly agree for all five constructs. 


\section{Results}

\section{Measurement Model}

Firstly, the measurement model of the study needs to achieve validity, reliability and unidimensionality (Awang 2015). If the factor loading value for all items are positive with a minimum value of 0.6 , then the unidimensionality will be achieved (Hair, Black et al. 2010). Whereas, construct validity will be achieved when the fitness indexes for the measurement model gain three model fit types ((Awang, 2015).. For achieving Discriminant validity, it is necessary that all constructs of the model are not to be highly correlated. Additionally, if the Average Variance Extracted (AVE) value is 0.5 or more then convergent validity will be achieved (Hair, Black et al. 2010).. Whereas, if Composite Reliability (CR) and AVE minimum value show 0.6 and 0.5 respectively then construct reliability will be achieved (Awang, 2015, Hair et al., 2010). The Internal reliability among the items will be achieved when the value of Cronbach Alpha shows the minimum value is 0.7 or more (Nunnally 1978). The Figure 2 indicate the measurement model of motivation, empowerment, organizational culture, and organizational commitment constructs have met the requirement for unidimensionality as well as construct validity.

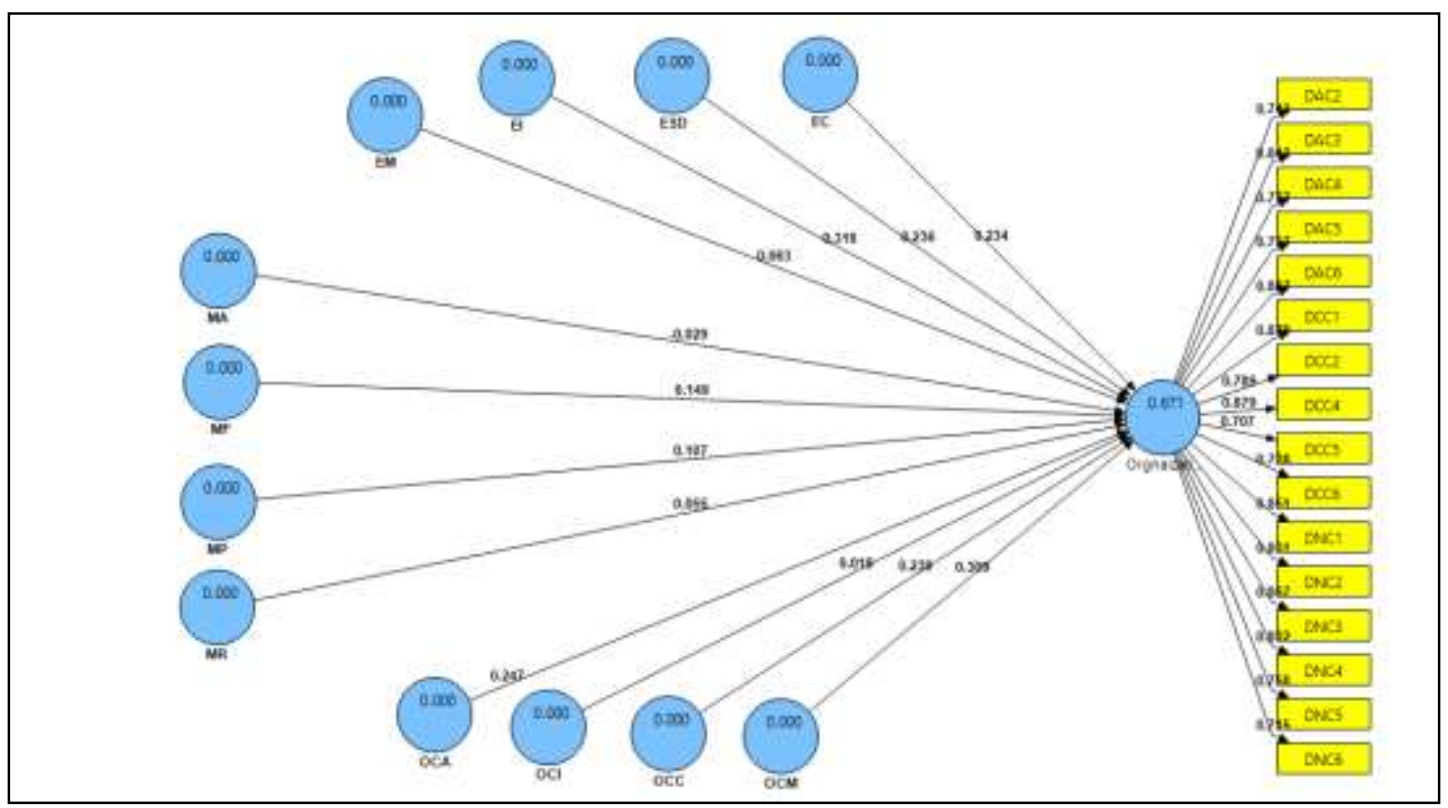

Figure. 2. Variance Explained through direct relationship

Table 1 shown factor loading value for every item together, CR and AVE for every construct. The reason for selecting composite reliability over Cronbach's alpha is that the estimates provided by composite reliability coefficient are much less biased than the Cronbach's alpha coefficients; this is because the Cronbach's alpha assumes that the contribution of all the items is equal towards that particular variable; it does consider the contribution of individual loadings (Barclay, Higgins et al. 1995, Götz, Liehr-Gobbers et al. 2010). 
Table 2: Loadings, Composite Reliability and Average Variance Extracted

\begin{tabular}{|c|c|c|c|}
\hline $\begin{array}{l}\text { Latent Constructs } \\
\text { \& Items }\end{array}$ & Loadings & $\begin{array}{l}\text { Average variance } \\
\text { Extracted (AVE) }\end{array}$ & $\begin{array}{l}\text { Composite } \\
\text { Reliability }\end{array}$ \\
\hline Organizational commitment & & 0.64 & 0.94 \\
\hline DAC2 & 0.742 & & \\
\hline DAC3 & 0.842 & & \\
\hline DAC4 & 0.778 & & \\
\hline DAC5 & 0.798 & & \\
\hline DAC6 & 0.885 & & \\
\hline DCC1 & 0.877 & & \\
\hline DCC2 & 0.79 & & \\
\hline DCC4 & 0.877 & & \\
\hline DCC5 & 0.706 & & \\
\hline DCC6 & 0.708 & & \\
\hline DNC1 & 0.851 & & \\
\hline DNC2 & 0.8 & & \\
\hline DNC3 & 0.866 & & \\
\hline DNC4 & 0.802 & & \\
\hline DNC5 & 0.758 & & \\
\hline DNC6 & 0.716 & & \\
\hline Motivation Appreciation & & 0.70 & 0.90 \\
\hline MA1 & 0.875 & & \\
\hline M12 & 0.844 & & \\
\hline MA3 & 0.769 & & \\
\hline MA4 & 0.866 & & \\
\hline Motivation Facilities & & 0.65 & 0.90 \\
\hline MF1 & 0.896 & & \\
\hline MF2 & 0.765 & & \\
\hline MF3 & 0.703 & & \\
\hline MF4 & 0.736 & & \\
\hline MF5 & 0.933 & & \\
\hline Motivation Promotion \&Growth & & 0.60 & 0.86 \\
\hline MP1 & 0.768 & & \\
\hline MP2 & 0.818 & & \\
\hline MP3 & 0.756 & & \\
\hline MP4 & 0.765 & & \\
\hline Motivation Reward & & 0.66 & 0.90 \\
\hline MR1 & 0.776 & & \\
\hline MR2 & 0.876 & & \\
\hline MR3 & 0.794 & & \\
\hline MR4 & 0.785 & & \\
\hline MR5 & 0.836 & & \\
\hline Empowerment Meaning & & 0.67 & 0.86 \\
\hline EM1 & 0.789 & & \\
\hline EM2 & 0.821 & & \\
\hline
\end{tabular}




\begin{tabular}{|c|c|c|c|}
\hline EM3 & 0.854 & & \\
\hline Empowerment Competence & & 0.61 & 0.86 \\
\hline EC1 & 0.8 & & \\
\hline EC2 & 0.741 & & \\
\hline EC3 & 0.778 & & \\
\hline EC4 & 0.822 & & \\
\hline Empowerment Self-Determent & & 0.71 & 0.88 \\
\hline ESD1 & 0.775 & & \\
\hline ESD2 & 0.892 & & \\
\hline ESD3 & 0.869 & & \\
\hline Empowerment Impact & & 0.66 & 0.87 \\
\hline El1 & 0.709 & & \\
\hline $\mathrm{EI} 2$ & 0.857 & & \\
\hline $\mathrm{EI3}$ & 0.836 & & \\
\hline EI4 & 0.794 & & \\
\hline Organization Culture Mission & & 0.69 & 0.90 \\
\hline OCM1 & 0.888 & & \\
\hline $\mathrm{OCM} 2$ & 0.715 & & \\
\hline OCM4 & 0.896 & & \\
\hline OCM5 & 0.815 & & \\
\hline Organization Culture Adaptability & & 0.67 & 0.89 \\
\hline OCA1 & 0.857 & & \\
\hline OCA2 & 0.719 & & \\
\hline OCA3 & 0.801 & & \\
\hline OCA4 & 0.892 & & \\
\hline Organization culture Involvement & & 0.71 & 0.92 \\
\hline $\mathrm{OCl} 2$ & 0.916 & & \\
\hline $\mathrm{OCl} 3$ & 0.877 & & \\
\hline $\mathrm{OCl} 4$ & 0.813 & & \\
\hline $\mathrm{OCl} 5$ & 0.727 & & \\
\hline OCI6 & 0.873 & & \\
\hline Organization culture consistency & & 0.65 & 0.84 \\
\hline OCC1 & 0.85 & & \\
\hline OCC2 & 0.86 & & \\
\hline OCC4 & 0.7 & & \\
\hline
\end{tabular}

According to Awang (2015) and Fornell and Larcker (1981) one way of achieving Discriminant validity is the correlation between independent variables must be less than 0.85 . Second criterion of Discriminant validity is when the diagonal values (i.e. $\sqrt[2]{A V E}$ for the respective construct) in the table will be higher than any values in their rows, and columns respectively then Discriminant validity will be achieved (Fornell and Larcker 1981). Since, the value in diagonal is higher than any values in its row and column in Table 3 , therefore this study has achieved the discriminant validity for the model. 
INTERNATIONAL JOURNAL OF ACADEMIC RESEARCH IN BUSINESS AND SOCIAL SCIENCES

Vol. 9, No. 9, September, 2019, E-ISSN: 2222-6990 @ 2019 HRMARS

Table 3: Latent Variable Correlations and Square roots of Average Variance Extracted

\begin{tabular}{ccccc}
\hline Construct & Motivation & Empowerment & Organizational culture & Commitment \\
\hline Motivation & $\mathbf{0 . 8 3 9}$ & & & \\
\hline Empowerment & 0.2030 & $\mathbf{0 . 8 7 8}$ & & \\
\hline $\begin{array}{c}\text { Organizational } \\
\text { culture }\end{array}$ & 0.247 & 0.264 & $\mathbf{0 . 7 7 7}$ & \\
\hline Commitment & 0.684 & 0.631 & 0.673 & $\mathbf{0 . 8 5 7}$ \\
\hline
\end{tabular}

\section{Structural Model}

As shown in Figure 4, the hypotheses $\mathrm{H} 1, \mathrm{H} 2$ and $\mathrm{H} 3$ are supported. In $\mathrm{H} 1$, Motivation has a significant positive effect on organizational commitment $(\beta=0.161, t=1.784)$. Hence $H_{1}$ is supported. In $\mathrm{H} 2$, empowerment has a significant positive effect on organizational commitment ( $\beta=0.476 ; t=7.321$ ), thus $\mathrm{H}_{2}$ is supported and in $\mathrm{H} 3$, Organizational culture has a significant positive effect on organizational commitment $(\beta=-0.187 ; t=2.81)$, which is mean is supported. Table 4 indicates that in the structural model the predictor (i.e. Motivation, empowerment and OC) of organizational commitment explains $0.67 \%$ of its variance

Table 4 Squared Multiple Correlations $\left(\mathrm{R}^{2}\right)$

\begin{tabular}{ll}
\hline Construct & Estimate $\left(R^{2}\right)$
\end{tabular}

$\begin{array}{ll}\text { Organizational Commitment } & 0.67\end{array}$

The above Table 4 indicates that the predictors of organizational commitment explain $0.67 \%$ of its variance. In other arguments, the error variance of organizational commitment is about $33 \%$ of the variance of organizational commitment.

Table 5 Effect Sizes of the Latent Variables on Cohen's (1988) Recommendation

\begin{tabular}{ccccc}
\hline Construct & Path & Construct & f-squared & Effect size \\
\hline $\begin{array}{c}\text { Organizational } \\
\text { Commitment }\end{array}$ & $\leftarrow$ & Motivation & 0.345 & moderate \\
\hline $\begin{array}{c}\text { Organizational } \\
\text { Commitment }\end{array}$ & $\leftarrow$ & Empowerment & .292 & moderate \\
\hline $\begin{array}{c}\text { Organizational } \\
\text { Commitment }\end{array}$ & $\leftarrow$ & OC & .033 & small \\
\hline
\end{tabular}

Table 5 shows the relative effect of a specific exogenous latent variable on endogenous latent variable(s) by means of changes in the R-squared values. The effect size is calculated as the increase in R-squared value of the latent variable to which the path is connected; relative to the latent variable's proportion of unexplained variance (Chin 1998). 


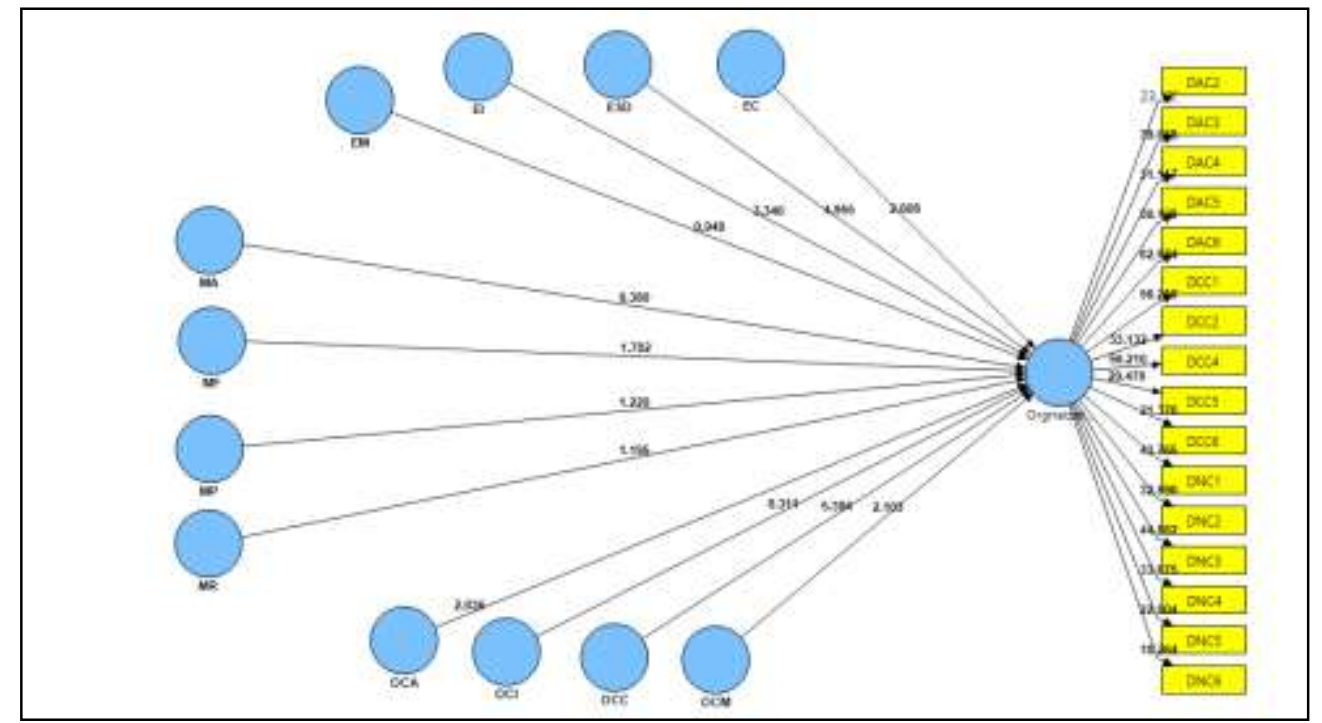

Figure 3: Structural Model

Table 6. Structural Model Assessment

\begin{tabular}{|c|c|c|c|}
\hline Hypothesis & $\begin{array}{c}\text { Path } \\
\text { coefficient }\end{array}$ & T value & Results \\
\hline $\mathrm{H} 1$ & 0.161 & 1.78 & Supported \\
\hline $\mathrm{H} 2$ & 0.476 & 7.32 & Supported \\
\hline $\mathrm{H} 3$ & 0.187 & 2.81 & Supported \\
\hline
\end{tabular}

Originally, $\mathrm{H}_{1}$ proposed that motivation relates positively to organizational commitment. Results showed that path coefficient, and $T$ value and $(\beta=0.161, t=1.784)$. Hence $H_{1}$ is supported and this result line with Van der Voet, Steijn et al. (2017) and Laschinger, Read et al. (2016). Furthermore, the results indicated that empowerment positively associated with organizational commitment $(\beta=0.476 ; t=7.321)$, thus $\mathrm{H}_{2}$ is supported and line with Han, Seo et al. (2016). Moreover, H3 proposed that the relationship between organization culture and organizational commitment is positively significant $(\beta=-0.187 ; t=2.81)$, which is mean is supported this hypotheses result is line with Mustafa, llyas et al. (2016) and with Masoulah and Allahyari (2017).

The result in Table 3 showed that the level of a CR it showed is large for all constructs in absolute value is 0.05 . In other words, the effects of three constructs (i.e., motivation, empowerment and $\mathrm{OC}$ ) on organizational commitment construct are highly significant. Hence, this research suggested that there is a straightforward need to give more attention on motivation, empowerment and $\mathrm{OC}$ for getting better organizational commitment and which will ensure better performance of municipality offices in Jordan. 


\section{Contribution of the Study}

This study has expanded our understanding relating to social exchange theory and outlining the important role of motivation, empowerment and $\mathrm{OC}$ for better organizational commitment as well as this study is the extension on top up earlier studies about the effects of motivation, empowerment and $\mathrm{OC}$ on organizational commitment. This study has also outlined that motivation is significant for organizational commitment prediction as well as, empowerment and $\mathrm{OC}$ is also significant for organizational commitment. Thus, this study can work as a directing compass for scholars of management arena to understand what further empirical associations they could possibly bring towards the organizational commitment. This study has made a notable stride and outlines that motivation, empowerment and OC has a strong effect on organizational commitment of municipalities in Jordan.

\section{Limitations and Scope for Future Studies}

Despite the significant results and notable implications, this study also has some limitations. At first, the study used cross-sectional research design which at times restricts from drawing causal explanations. In this regard, longitudinal research study could be a prominent arena for future scholars on the framework. In addition, to this, it is essential to understand that there is a need for robust underlining of prospects that could help to improve motivation, empowerment and organizational culture which resulting to get better organizational commitment. Accordingly, since the present study only examined motivation, empowerment and organizational culture, future scholars may attempt to test the impact of other variables for getter organizational commitment.

\section{Conclusion}

The present study has provided empirical confirmation towards the concept of organizational commitment through outlining how motivation, empowerment and organizational culture can influence. This study found motivation, empowerment and organizational culture have Significant effect on organizational commitment. Hence, the examined motivation, empowerment and organizational culture are connected with better performance of employees which generates superior organizational commitment. The findings provide evidence to support the explanations of social exchange theory and how examined motivation, empowerment and organizational culture could be influential issue for gaining better organizational commitment. The study has also forwarded important implications for scholars and practitioners to help facilitate their understanding and comprehension regarding examined motivation, empowerment and organizational culture, and organizational commitment perceptions. The findings have empirically strived to guide the policy makers in Jordan as well as future researchers to see the role of examined motivation, empowerment and organizational culture to gain better organizational commitment, especially in the developing countries.

\section{Recommendation and Suggestion}

From a practical viewpoint, the findings of this study provide important contributions and implications for practitioners and decision-makers. Additionally, the current study provides a valuable approach to how motivation, empowerment, organizational culture could improve the organizational commitment level among municipalities in Jordan, it is hoped the managers of the municipalities apply the findings from the study in order to enhance the level 
of organizational commitment among municipalities in Jordan, which, as a result, can minimize the turnover rate among the employees and maximize the organizational performance.

\section{References}

Agyapong, A. (2017). Local Government And Domestic Revenue Mobilisation: The Case Of East Gonja District Assmbly In The Nothern Region (Doctoral dissertation).

Armstrong, M. (2016). How to manage people. Kogan Page Publishers.

Awang, Z. (2015). SEM made simple: A gentle approach to learning Structural Equation Modeling. MPWS Rich Publication.

Barclay, D., Higgins, C., \& Thompson, R. (1995). The partial least squares (PLS) approach to casual modeling: personal computer adoption ans use as an Illustration.

Bowen, K. J., Cradock-Henry, N. A., Koch, F., Patterson, J., Häyhä, T., Vogt, J., \& Barbi, F. (2017). Implementing the "Sustainable Development Goals": towards addressing three key governance challenges-collective action, trade-offs, and accountability. Current opinion in environmental sustainability, 26, 90-96.

Chin, W. W. (1998). The partial least squares approach to structural equation modeling. Modern methods for business research, 295(2), 295-336.

Conger, J. A., \& Kanungo, R. N. (1988). The empowerment process: Integrating theory and practice. Academy of management review, 13(3), 471-482.

Fornell, C., \& Larcker, D. F. (1981). Evaluating structural equation models with unobservable variables and measurement error. Journal of marketing research, 18(1), 39-50.

Gao-Urhahn, X., Biemann, T., \& Jaros, S. J. (2016). How affective commitment to the organization changes over time: A longitudinal analysis of the reciprocal relationships between affective organizational commitment and income. Journal of Organizational Behavior, 37(4), 515-536.

Götz, O., Liehr-Gobbers, K., \& Krafft, M. (2010). Evaluation of structural equation models using the partial least squares (PLS) approach. In Handbook of partial least squares (pp. 691711). Springer, Berlin, Heidelberg.

Grönroos, C. (2016). Internationalization strategies for services: a retrospective. Journal of Services Marketing, 30(2), 129-132.

Hair, J. F., Black, W. C., Babin, B. J., \& Anderson, R. E. (2010). Multivariate data analysis: Global edition.

Han, S. H., Seo, G., Yoon, S. W., \& Yoon, D. Y. (2016). Transformational leadership and knowledge sharing: Mediating roles of employee's empowerment, commitment, and citizenship behaviors. Journal of Workplace Learning, 28(3), 130-149.

Hartnell, C. A., Kinicki, A. J., Lambert, L. S., Fugate, M., \& Doyle Corner, P. (2016). Do similarities or differences between CEO leadership and organizational culture have a more positive effect on firm performance? A test of competing predictions. Journal of Applied Psychology, 101(6), 846.

Henson, J. A., \& Beehr, T. (2018). Subordinates' core self-evaluations and performance predict leader-rated LMX. Leadership \& Organization Development Journal, 39(1), 150-168.

Jones, B. J. (2017). Positive Public Service: Turning Purpose Into Progress By Changing How Government Works From the Inside. 
Kabat-Farr, D., Cortina, L. M., \& Marchiondo, L. A. (2018). The emotional aftermath of incivility: Anger, guilt, and the role of organizational commitment. International Journal of Stress Management, 25(2), 109.

Khan, W., \& Iqbal, Y. (2013). An investigation of the relationship between work motivation (intrinsic \& extrinsic) and employee engagement: a study on Allied Bank of Pakistan.

Khanjari, L. (2017). Investigating the relationship between social responsibility and improving organizational commitment in employees of Tehran Ghavamin Bank with respect to the mediating role of psychological empowerment. Journal of Fundamental and Applied Sciences, 9(1S), 96-121.

Khansa, L., Barkhi, R., Ray, S., \& Davis, Z. (2018). Cyberloafing in the workplace: mitigation tactics and their impact on individuals' behavior. Information Technology and Management, 19(4), 197-215.

Laschinger, H. K., Read, E., \& Zhu, J. (2016). Employee empowerment and organizational commitment. In Handbook of Employee Commitment. Edward Elgar Publishing.

Lê, N. Đ. K., \& Bùi, T. M. T. (2017). Research Effectiveness of Corporate Culture to Employee's Loyalty at Lilama 7 Joint Stock Company.

Liao, C., Wayne, S. J., Liden, R. C., \& Meuser, J. D. (2017). Idiosyncratic deals and individual effectiveness: The moderating role of leader-member exchange differentiation. The Leadership Quarterly, 28(3), 438-450.

Liden, R. C., Wayne, S. J., \& Sparrowe, R. T. (2000). An examination of the mediating role of psychological empowerment on the relations between the job, interpersonal relationships, and work outcomes. Journal of applied psychology, 85(3), 407.

Locke, E. A. (1997). The motivation to work: What we know. Advances in motivation and achievement, 10(2), 375-412.

Masouleh, Z. D., \& Allahyari, M. S. (2017). The predictability of organisational culture for commitment among faculty members: evidence from Iran higher education. International Journal of Management in Education, 11(1), 94-109.

Meyer, J. P., \& Allen, N. J. (1997). Commitment in the workplace: Theory, research, and application. Sage.

Meyer, J. P., Allen, N. J., \& Smith, C. A. (1993). Commitment to organizations and occupations: Extension and test of a three-component conceptualization. Journal of applied psychology, 78(4), 538.

Meyer, J. P., \& Herscovitch, L. (2001). Commitment in the workplace: Toward a general model. Human resource management review, 11(3), 299-326.

Mueller, B. H., \& Lee, J. (2002). Leader-member exchange and organizational communication satisfaction in multiple contexts. The Journal of Business Communication (1973), 39(2), 220-244.

Mustafa, G., Ilyas, M., \& Rehman, A. (2016). Do the Employees' Job Satisfaction interferes organizational Culture and Affective Commitment Relationship: Test of Bootstrap Mediation. J. Appl. Environ. Biol. Sci, 6(5), 125-133.

Nunnally, J. (1978). C.(1978). Psychometric theory, 2.

Pinder, C. C. (1998). Motivation in work organizations.

Porter, T. H., Riesenmy, K. D., \& Fields, D. (2016). Work environment and employee motivation to lead: Moderating effects of personal characteristics. American Journal of Business, 31(2), 66-84.

Rose-Ackerman, S. (2017). What does "governance" mean?. Governance, 30(1), 23-27. 
Spreitzer, G. M. (1995). Psychological empowerment in the workplace: Dimensions, measurement, and validation. Academy of management Journal, 38(5), 1442-1465.

Thomas, K. W., \& Velthouse, B. A. (1990). Cognitive elements of empowerment: An "interpretive" model of intrinsic task motivation. Academy of management review, 15(4), 666-681.

Van der Voet, J., Steijn, B., \& Kuipers, B. S. (2017). What's in it for others? The relationship between prosocial motivation and commitment to change among youth care professionals. Public Management Review, 19(4), 443-462.

Yokel, R. A., Allen, D. D., \& Meyer, J. J. (1994). Studies of aluminum neurobehavioral toxicity in the intact mammal. Cellular and molecular neurobiology, 14(6), 791-808.

Zohar, D., \& Polachek, T. (2017). Using event-level data to test the effect of verbal leader behavior on follower leadership perceptions and job performance: A randomized field experiment. Group \& Organization Management, 42(3), 419-449. 